UDC 352.073(477)(07)

https://doi.org/10.32689/2617-22242020-4(24)-173-188

\section{Коробчинська Наталія Валерї̈вна,} аспірантка, Комунальний вищий навчальний заклад "Вінницька академія неперервної освіти", 21000, м. Вінниия, вул. Грушевського, 13, тел.: (0432)-55-65-68, e-mail:natakorob1980@gmail.com, https:// orcid.org/0000-0003-4947-0911

Коробиинская Наталья Валерьевна, аспирантка, Коммунальное высшее учебное заведение "Винниикая академия непрерывного образования”, 21000, 2. Винниц, ул. Грушевского, 13, тел.: (0432)-55-65-68,e-mail:natakorob1980@ gmail.com, https://orcid.org/0000-00034947-0911

Korobchynska Nataliia Valeriivna, postgraduate student, Municipal Higher Education Institution "Vinnytsia Academy of Continuing Education", Vinnytsia, st.

Hrusherskoho, 13, tel.: (0432)-55-65-68, e-mail:natakorob1980@gmail.com, https://orcid. org/0000-0003-4947-0911

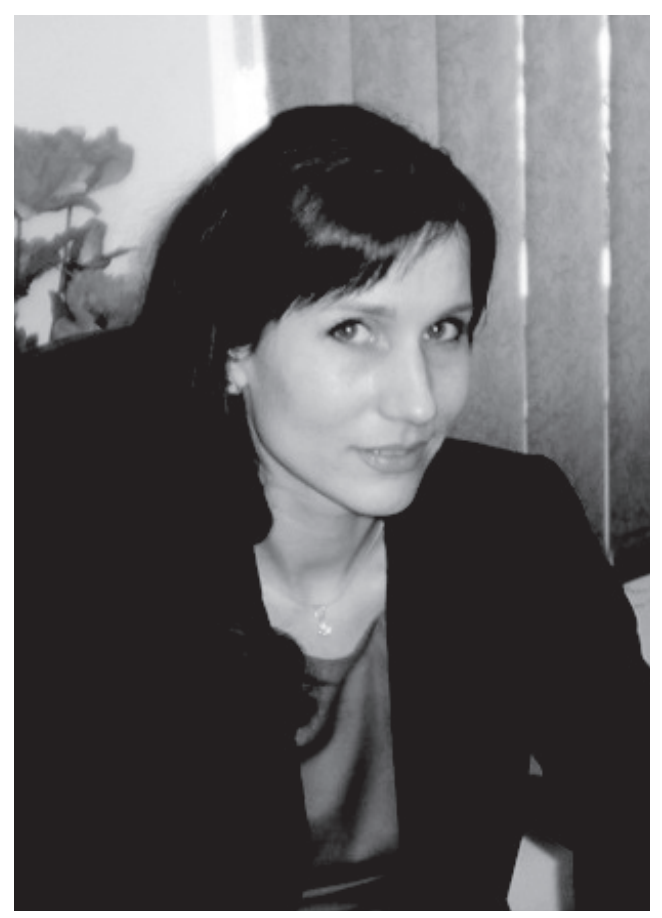

\title{
ЕЛЕКТРОННА СИСТЕМА ОХОРОНИ ЗДОРОВ'Я ЯК ІНСТРУМЕНТ МОНІТОРИНГУ В СФЕРІ ОХОРОНИ ЗДОРОВ'Я ОБ'ЕДНАНОї ТЕРИТОРІАЛЬНОЇ ГРОМАДИ: НОРМАТИВНО-ПРАВОВЕ ЗАБЕЗПЕЧЕННЯ
}

Анотація. Викладено, що з моменту початку досліджень у напрямі використання інформаційних технологій у сфері охорони здоров'я минуло понад 60 років, проте повної ясності у визначенні найкращої стратегії інформатизації та діяльності електронної системи охорони здоров'я (ЕСОЗ) немає.

На сьогодні нормативно-правовими актами врегульовані інформатизація в галузі охорони здоров'я та порядок діяльності ЕСОЗ, збереження, захисту персональної та медичної інформації. Проте не врегульованими залишаються питання оцінки якості та механізмів моніторингу ЕСОЗ. Недостатньо вивченими є питання використання електронних інструментів для оцінки якості роботи системи охорони здоров'я, показників стану здоров'я населен- 
ня, економічних показників діяльності системи охорони здоров’я. На цьому етапі розвитку електронної системи охорони здоров’я впроваджено процес автоматизації, проте є потреба у розвитку механізмів обробки та аналізу інформації, використання ЕСОЗ як інструменту для систематичного та вчасного моніторингу ефективності діяльності галузі охорони здоров'я, зокрема на рівні об'єднаної територіальної громади в умовах зміни адміністративно-територіального устрою, децентралізації, формування та розвитку територіальних громад. Для громади загалом є суттєвою інформація щодо стану охорони здоров'я не стільки на адміністративній території, скільки на території громади. Інформатизація та ЕСОЗ може стати важливим інструментом для моніторингу системи охорони здоров’я на території населених пунктів, які входять до складу об’єднаної територіальної громади та обслуговують населення громади, а не окремого міста, селища тощо.

Окреслено основну мету та напрями діяльності ЕСО3 як інструменту для моніторингу процесу та результатів діяльності у сфері охорони здоров’я об'єднаної територіальної громади, розглянуто питання законодавчого регулювання щодо інформатизації у сфері охорони здоров’я та діяльності ЕСОЗ, відповідальності за порушення у сфері захисту інформації.

Ключові слова: інформатизація, галузь охорони здоров'я, електронна система охорони здоров'я, територіальна громада, показники діяльності, механізми моніторингу, нормативно-правова база, публічне управління та адміністрування.

\section{ЭЛЕКТРОННАЯ СИСТЕМА ЗДРАВООХРАНЕНИЯ КАК ИНСТРУМЕНТ МОНИТОРИНГА В СФЕРЕ ЗДРАВООХРАНЕНИЯ ОБЬЕДИНЕННОЙ ТЕРРИТОРИАЛЬНОЙ ОБЩИНЫ: НОРМАТИВНО-ПРАВОВОЕ ОБЕСПЕЧЕНИЕ}

Аннотация. Исследовано, что в направлении использования информационных технологий в сфере здравоохранения прошло более 60 лет, однако полной ясности в определении наилучшей стратегии информатизации и деятельности электронного здравоохранения (ЕСО3) нет.

На сегодня нормативно-правовыми актами урегулированы информатизация в области здравоохранения и порядок деятельности ЕСО3, хранения, защиты персональной и медицинской информации. Однако вопросы урегулирования оценки качества и механизмов мониторинга ЕСОЗ исследованы недостаточно. Недостаточно изученными являются и вопросы использования электронных инструментов для оценки качества работы системы здравоохранения, показателей состояния здоровья населения, экономических показателей деятельности системы здравоохранения. На данном этапе развития электронного здравоохранения внедрен процесс автоматизации, однако есть потребность в развитии механизмов обработки и анализа информации, использование ЕСОЗ как инструмента для систематического и своевременного мониторинга эффективности деятельности отрасли здравоохранения, в частности на уровне объединенной территориальной общи- 
ны в условиях изменения административно-территориального устройства, децентрализации, формирования и развития территориальных общин. Для общества в целом является существенной информация о состоянии здравоохранения не столько на административной территории, сколько на территории общины. Информатизация и ЕСОЗ может стать важным инструментом для мониторинга системы здравоохранения на территории населенных пунктов, входящих в состав объединенной территориальной общины, которые обслуживают население общины, а не отдельного города, поселка.

Обозначены основные цели и направления деятельности ЕСОЗ как инструмента для мониторинга процесса и результатов деятельности в сфере здравоохранения объединенной территориальной общины, рассмотрены вопросы законодательного регулирования по информатизации в сфере здравоохранения и деятельности ЕСОЗ, ответственности за нарушения в сфере защиты информации.

Ключевые слова: информатизация, здравоохранение, электронная система здравоохранения, территориальная община, показатели деятельности, механизмы мониторинга, нормативно-правовая база, публичное управление и администрирование.

\section{ELECTRONIC HEALTHCARE SYSTEM AS A MONITORING TOOL IN THE FIELD OF HEALTHCARE OF THE UNITED TERRITORIAL COMMUNITY: REGULATORY LAW}

Abstract. More than 60 years have passed since the beginning of research on the use of information technology in the field of healthcare, but there is no complete clarity in determining the best strategy for informatization and the operation of the electronic healthcare system (EHS).

At present, normative-legal acts regulate informatization in the field of healthcare and the order of activity of the EHS, storage, protection of personal and medical information. However, the issues of quality assessment and monitoring mechanisms of the EHS have not been resolved. The issues of using electronic tools to assess the quality of the healthcare system, indicators of the state of health of the population, economic indicators of the healthcare system are also insufficiently studied. At this stage of development of the electronic healthcare system, the automation process has been introduced, but there is a need to develop the mechanisms for processing and analyzing information, using the EHS as a tool for systematic and timely monitoring of healthcare performance, in particular at the level of the united territorial community in the conditions of change of the administrative-territorial system, decentralization, formation and development of the territorial communities. For the community as a whole, there is important information about the state of healthcare not so much in the administrative territory as in the community. Informatization and EHS can be an important tool for monitoring the healthcare system in the settlements that are part of a unified 
territorial community and serve the population of the community, rather than a single city, town, etc.

This study outlines the main purpose and activities of the EHS as a tool for monitoring the process and results of activities in the field of healthcare of the united territorial community, considered issues of legislation on informatization in the field of healthcare and activities of the EHS, liability for violations of in the field of information protection.

Keywords: informatization, healthcare sector, electronic healthcare system, territorial community, performance indicators, monitoring mechanisms, legal framework, public administration.

Постановка проблеми. На сьогодні в Україні проводиться інформатизація галузі охорони здоров'я, впроваджено електронну систему охорони здоров'я, триває їі розвиток, удосконалюються процеси та механізми діяльності. Прийнято низку нормативних документів, які регламентують діяльність електронної системи охорони здоров'я в сучасних умовах.

Встановлено, що якість роботи електронної системи охорони здоров'я залежить від налаштованих процесів, поставлених цілей, рівня фінансування, фахової підготовки медичних працівників тощо. Крім того, на якість результату впливає ефективність та відповідність механізмів моніторингу та контролю за якістю електронних медичних даних.

Доцільно налаштована електронна система охорони здоров'я на рівні об'єднаної територіальної громади може бути ефективним інструментом контролю за якістю надання медичної допомоги населенню громади, прогнозування потреб у тих чи інших видах медичної допомоги; оперативно забезпечувати інформацією для прийняття рішень в управлінні охороною здоров'я, допомагати проводити оцінку ефективності використання коштів для надання медичної допомоги населенню громади.

При всій очевидності мети та переваг інформатизації охорони здоров'я, досі лишаються питання вибору оптимальних механізмів моніторингу та дотримання якості роботи електронної системи охорони здоров'я. $€$ необхідність в дослідженні вітчизняного та зарубіжного досвіду за даним напрямом, оцінці переваг, недоліків та ризиків інформатизації. Потребують додаткового вивчення та узагальнення правові аспекти інформатизації та діяльності електронної системи охорони здоров'я в Україні.

Аналіз останніх досліджень та публікацій. Проблеми інформатизації медицини та впровадження госпітальних (лікарняних) інформаційних систем сьогодні перебувають у центрі наукового й практичного інтересу лікарів, організаторів, юристів та менеджерів охорони здоров'я. Неабиякий внесок у розробку зазначених питань зробили О. Баєва, Р. Василишин, М. Голубчиков, Я. Гулієв, А. Гусев, С. Дяченко, В. Качмар, 
О. Мінцер, В. Степанов, Н. Філіппова та ін. У той же час на сьогодні недостатньо вивченими є правові аспекти інформатизації вітчизняної медицини та потенційні ризики впровадження так званої системи E-health [1].

Погоджуємося з В. Ю. Степановим, який у своєму дослідженні зазначає, що комплексна інформатизація закладів охорони здоров'я дозволить: забезпечити швидкий доступ до поточної, найбільш повної і достовірної інформації (сюди входять усі дані про пацієнта, його амбулаторна карта, своєчасне надходження результатів аналізів, перегляд рентгенівських знімків та ін.); підвищити якість та доступність послуг, що надаються медичними установами пацієнтам; скоротити витрати робочого часу на обслуговування пацієнтів і управління медичним закладом за рахунок повної автоматизації рутинних операцій із заповнення паперових форм; позбавити лікарів і адміністрацію від працемісткого процесу складання звітів; уникнути втрат інформації; мінімізувати “людський фактор” помилки при формуванні статистичної звітності закладу тощо [2]. Тому розвиток та вдосконалення якості та ефективності діяльності електронної системи охорони здоров’я є вкрай важливими.

Мета статті - окреслити законодавчі підстави інформатизації у галузі охорони здоров'я та основні існуючі цілі діяльності електронної системи охорони здоров'я територіальної громади.

Виклад основного матеріалу. Інформатизація галузей діяльності об'єднаних територіальних громад - вимога та потреба сьогодення. Територіальна громада має свою систему охорони здоров'я, діяльність якої забезпечується в умовах децентралізації та місцевого самоврядування залежно від потреб мешканців громади. Впровадження електронних інструментів та ресурсів покращує доступність та керованість галузей об’єднаної громади, зокрема медичної галузі.

Так, інформатизація галузі охорони здоров'я Вінницької міської об'єднаної територіальної громади розпочата ще в 2011 році. На сьогодні громада має можливості не лише автоматизувати процес обліку медичних даних та формування звітів, а й використовувати електронну систему охорони здоров'я як інструмент для моніторингу діяльності галузі загалом, потужна реалізація інформатизації дає змогу проводити систематичний моніторинг та оцінку отриманих результатів у сфері охорони здоров’я громади. Результати реалізації заходів потребують детального вивчення та з'ясування отриманої користі, а також детального аналізу нормативно-правової бази.

В Україні прийнято ряд нормативно-правових актів, які регламентують впровадження інформатизації галузі охорони здоров’я та діяльність ЕСО3 (перелік наведено в табл. 1).

Вивчення та аналіз нормативних документів показали, що метою діяльності галузі охорони здоров’я є збереження життя та здоров'я людини [6]. Отже, впровадження та оптимізація заходів у сфері охорони здоров'я, які позитивно впливають на якість медичного обслуговування населення, є доцільними та вкрай важливими. 
Нормативно-правові акти, які регламентують інформатизацію в галузі охорони здоров'я та діяльність ЕСОЗ

\begin{tabular}{|c|c|c|}
\hline $\begin{array}{l}\text { № } \\
\text { пор. }\end{array}$ & $\begin{array}{c}\text { Назва нормативного } \\
\text { документа }\end{array}$ & Що регламентує \\
\hline 1 & 2 & 3 \\
\hline 1 & Конституція України & $\begin{array}{l}\text { Стаття } 3 \text { Конституції України свідчить про те, } \\
\text { що людина, ї̈ життя і здоров'я, честь і гідність, } \\
\text { недоторканність і безпека визнаються в Україні } \\
\text { найвищою соціальною цінністю. Права і свободи } \\
\text { людини та їх гарантії визначають зміст і спрямованість } \\
\text { діяльності держави. Держава відповідає перед } \\
\text { людиною за свою діяльність. Утвердження і } \\
\text { забезпечення прав і свобод людини є головним } \\
\text { обов'язком держави. } \\
\text { Статтею } 49 \text { Конституції України закріплено право } \\
\text { кожного на охорону здоров’я, медичну допомогу } \\
\text { та медичне страхування. Охорона здоров'я } \\
\text { забезпечується державним фінансуванням відповідних } \\
\text { соціально-економічних, медико-санітарних і } \\
\text { оздоровчо-профілактичних програм. } \\
\text { Держава створює умови для ефективного і доступного } \\
\text { для всіх громадян медичного обслуговування [6] }\end{array}$ \\
\hline 2 & $\begin{array}{l}\text { Українська Стратегія } \\
\text { розвитку системи } \\
\text { охорони здоров'я }\end{array}$ & $\begin{array}{l}\text { Українська Стратегія розвитку системи охорони } \\
\text { здоров'я базується на трьох фундаментальних } \\
\text { принципах, а саме: у центрі уваги та інтересу системи } \\
\text { охорони здоров'я повинна перебувати людина } \\
\text { (пацієнт), тож заходи системи повинні спрямовуватися } \\
\text { на задоволення потреб людини; якість, безпеку, } \\
\text { тривалість послуг, наближеність до громади та швидке } \\
\text { реагування на зміни. В Стратегії розвитку зазначено, } \\
\text { що система охорони здоров'я є системою, яка } \\
\text { повинна керувати стосунками між різними учасниками, } \\
\text { включаючи управлінців, надавачів послуг, отримувачів } \\
\text { послуг та дослідників, кожний з яких займає певну } \\
\text { нішу та має чітко визначену відповідальність. Таким } \\
\text { чином, система повинна базуватися на довірі, діалозі } \\
\text { та взаємній повазі усіх учасників, і ефективність усієї } \\
\text { системи в кінцевому підсумку залежатиме від якості } \\
\text { іх взаємодії. у Стратегії зазначено, що існує потреба } \\
\text { в оцінюванні впроваджених змін у сфері охорони } \\
\text { здоров'я та розробці дієвих механізмів моніторингу } \\
\text { отриманих результатів для вчасного реагування та } \\
\text { визначення напрямів дій. } \\
\text { Відповідно до Стратегії розвитку, система охорони } \\
\text { здоров'я має бути зорієнтована на очікувані результати } \\
\text { (показники здоров'я, фінансову захищеність пацієнтів, } \\
\text { економічну ефективність та задоволеність послугами), } \\
\text { повинна керувати процесом прийняття рішень на усіх } \\
\text { рівнях; оцінка роботи персоналу повинна базуватися на } \\
\text { результативності наданих послуг, здійснюватися }\end{array}$ \\
\hline
\end{tabular}


Закінчення табл. 1

\begin{tabular}{|c|c|c|}
\hline 1 & 2 & 3 \\
\hline & & $\begin{array}{l}\text { регулярно та постійно удосконалюватися. Ця вимога } \\
\text { є суттєвим пріоритетом для створення якісної та } \\
\text { працюючої інформаційної бази, за даними якої } \\
\text { приймаються відповідні рішення. У Стратегії зазначено, } \\
\text { що наразі наявні доказові дані є неякісними та } \\
\text { обмеженими. } \\
\text { у Стратегії розвитку також зазначено, що } \\
\text { зосередження на впровадження поставлених цілей } \\
\text { означає, що недостатньо мати хороші ідеї, але важливо } \\
\text { розробляти, впроваджувати та моніторити виконання } \\
\text { детальних планів реформування, які чітко визначають } \\
\text { відповідальність, часові рамки, механізми звітності. } \\
\text { Стратегія розвитку системи охорони здоров'я } \\
\text { передбачає забезпечення інформацією у сфері } \\
\text { охорони здоров'я, прозорість та підзвітність, нагляд/ } \\
\text { екстрене реагування. Галузь охорони здоров'я } \\
\text { зобов'язана володіти даними про порівняльну } \\
\text { ефективність та результативність і повинна } \\
\text { забезпечити доступну, достовірну, правдиву, своєчасну } \\
\text { і прозору інформацію стосовно стану здоров'я } \\
\text { населення та результатів діяльності сфери охорони } \\
\text { здоров'я. } \\
\text { Стратегія розвитку зазначає, що інформація є } \\
\text { важливою частиною вдосконалення управлінських } \\
\text { заходів. Зміцнення потужності та використання } \\
\text { інформаційних технологій підвищує якість даних, обмін, } \\
\text { використання та поширення знань та інформації. } \\
\text { Це, своєю чергою, сприяє підвищенню прозорості, } \\
\text { підзвітності та економічної ефективності надання } \\
\text { послуг, посилюючи роль зацікавлених сторін. Нові } \\
\text { ІТ-послуги зміцнюють потенціал та розширюють } \\
\text { можливості у сфері планування, реалізації і моніторингу } \\
\text { програм у галузі охорони здоров'я. Інформатизація } \\
\text { охорони здоров'я та створення електронної системи } \\
\text { охорони здоров'я (ЕСоз) стає інструментом для } \\
\text { оперативного отримання якісної, достовірної, } \\
\text { доступної медичної інформації [7] }\end{array}$ \\
\hline 3. & $\begin{array}{l}\text { “Основи європейської } \\
\text { політики та стратегія } \\
\text { для XXI століття” } \\
\text { Всесвітньої } \\
\text { організації охорони } \\
\text { здоров'я }\end{array}$ & $\begin{array}{l}\text { Визначає необхідність підвищення рівня розвитку } \\
\text { систем та послуг інформаційного забезпечення } \\
\text { охорони здоров'я }\end{array}$ \\
\hline
\end{tabular}

У ракурсі цього питання Конституція України та Українська Стратегія розвитку системи охорони здоров'я, “Основи європейської політики та стратегія для XXI сто- ліття", затверджені Всесвітньою організацією охорони здоров'я, зумовлюють якісну діяльність системи охорони здоров'я та впровадження інформаційних технологій. 
Отже, розвиток та вдосконалення якості та ефективності діяльності системи охорони здоров’я є украй важливими, в сучасних реаліях інформатизація галузі охорони здоров'я, як інструмент для ефективної роботи галузі, є вимогою та потребою.

У 2017 році в Україні розпочалася реформа системи охорони здоров'я. Важливим інструментом впрова- дження реформи є створення сучасної електронної системи, що дозволить значно підвищити ефективність та прозорість охорони здоров'я. Механізм впровадження та розвиток інформатизаціі, функціонування електронної системи охорони здоров’я передбачений у ряді нормативно-правових актів, прийнятих в умовах реформування галузі охорони здоров’я (перелік наведено в табл. 2).

Таблиця 2

Нормативно-правові акти, які регламентують інформатизацію в галузі охорони здоров'я та діяльність ЕСОЗ в умовах реформування

\begin{tabular}{|c|c|c|}
\hline $\begin{array}{l}\text { № } \\
\text { nор. }\end{array}$ & $\begin{array}{c}\text { Назва нормативного } \\
\text { документа }\end{array}$ & Що регламентує \\
\hline 1 & 2 & 3 \\
\hline 1 & 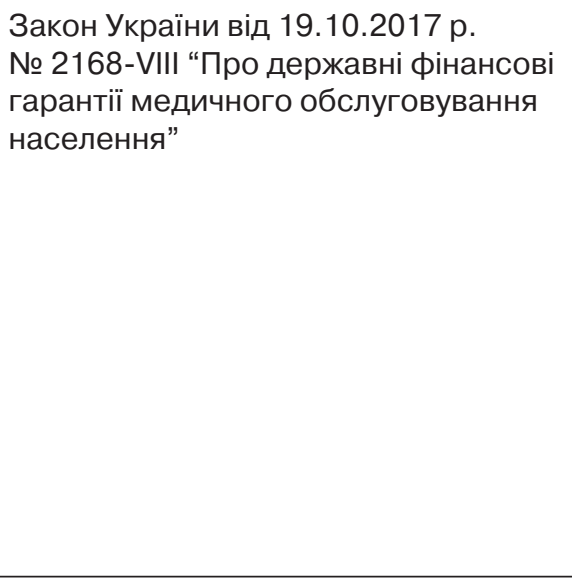 & $\begin{array}{l}\text { Визначає ЕСОЗ як інформаційно- } \\
\text { телекомунікаційну систему, } \\
\text { що забезпечує автоматизацію } \\
\text { ведення обліку медичних послуг та } \\
\text { управління медичною інформацією } \\
\text { шляхом створення, розміщення, } \\
\text { оприлюднення та обміну } \\
\text { інформацією, даними і документами } \\
\text { в електронному вигляді, до складу } \\
\text { якої входять центральна база даних } \\
\text { та електронні медичні інформаційні } \\
\text { системи, між якими забезпечено } \\
\text { автоматичний обмін інформацією, } \\
\text { даними та документами через } \\
\text { відкритий програмний інтерфейс [9] }\end{array}$ \\
\hline 2 & $\begin{array}{l}\text { Постанова КМУ “Деякі питання } \\
\text { електронної системи охорони } \\
\text { здоров'я” від 25.04.2018 р. № } 411\end{array}$ & $\begin{array}{l}\text { Встановлено порядок } \\
\text { функціонування електронної системи } \\
\text { охорони здоров'я [11] }\end{array}$ \\
\hline 3 & $\begin{array}{l}\text { Закони України: } \\
\text { - “Основи законодавства України } \\
\text { про охорону здоров'я"; } \\
\text { - “Про інформацію"; } \\
\text { - “Про електронні документи та } \\
\text { електронний документообіг”; } \\
\text { - “Про електронні довірчі послуги”; } \\
\text { - “Про Єдиний державний } \\
\text { демографічний реєстр та } \\
\text { документи, що підтверджують } \\
\text { громадянство України, посвідчують } \\
\text { особу чи ї̈ спеціальний статус" }\end{array}$ & $\begin{array}{l}\text { Передбачений механізм } \\
\text { функціонування електронної системи } \\
\text { охорони здоров'я [12] }\end{array}$ \\
\hline
\end{tabular}


Закінчення табл. 2

\begin{tabular}{|c|l|l|}
\hline 1 & \multicolumn{1}{|c|}{2} & \multicolumn{1}{|c|}{3} \\
\hline 4 & $\begin{array}{l}\text { Порядок організації електронної } \\
\text { інформаційної взаємодії державних } \\
\text { електронних інформаційних } \\
\text { ресурсів, затверджений постановою } \\
\text { Кабінету Міністрів України від } \\
\text { 10.05.2018 р. № 357 }\end{array}$ & $\begin{array}{l}\text { Роз'яснює питання організації } \\
\text { електронної інформаційної взаємодії } \\
\text { [13] }\end{array}$ \\
\hline
\end{tabular}

Так, протягом 2017-2020 рр. відбувся ряд системних зрушень у сфері інформатизації охорони здоров'я, було прийнято Закон України "Про державні фінансові гарантії медичного обслуговування населення", ряд підзаконних актів, якими врегульовано діяльність електронної системи охорони здоров'я (ECO3) та інституцій, що мають іiї впроваджувати - Міністерство охорони здоров'я (МО3), Національна служба здоров’я України (НСЗУ), Державне підприємство "Електронне здоров'я".

Дані в інформаційно-телекомунікаційних системах у рамках ЕСОЗ мають оброблятись відповідно до визначеної, законної мети та з урахуванням вимог законодавства у сфері захисту персональних даних та тех- нічного захисту даних в інформаційно-телекомунікаційних системах.

Важливим є захист медичної інформації. Будь-яка електронна система має включати механізм захисту для забезпечення збереженості документів, забезпечення безпечного доступу, забезпечення достовірності документів, протоколювання дій користувачів. Система обміну даними повинна забезпечити не тільки передачу інформації, а й її збереження від викрадення чи модифікації, а також мати можливість її швидкого відновлення.

Необхідність забезпечення захисту інформації, а саме створення комплексної системи захисту інформації (КСЗІ) в автоматизованих системах визначається передусім вимогами нормативно-правових документів (табл. 3).

Таблиця 3

\section{Нормативні документи, які регулюють збір та обробку персональних даних пацієнта та захист інформації у ЕСОЗ}

\begin{tabular}{|c|l|l|}
\hline $\begin{array}{c}\text { № } \\
\text { пор. }\end{array}$ & $\begin{array}{c}\text { Назва нормативного } \\
\text { документа }\end{array}$ & \multicolumn{1}{|c|}{ Що регламентує } \\
\hline 1 & \multicolumn{1}{|c|}{2} & \multicolumn{1}{c|}{3} \\
\hline 1 & $\begin{array}{l}\text { Наказ Міністерства } \\
\text { охорони здоров'я } \\
\text { України від } \\
28.02 .2020 \text { р. № } 587\end{array}$ & $\begin{array}{l}\text { Затверджено порядок ведення Реєстру медичних } \\
\text { записів, записів про направлення та рецептів в } \\
\text { електронній системі охорони здоров'я. } \\
\text { Відповідно до зазначеного порядку обробка } \\
\text { персональних даних у Реєстрі здійснюється } \\
\text { з метою забезпечення реалізації програми } \\
\text { державних гарантій медичного обслуговування } \\
\text { населення, а також для забезпечення } \\
\text { функціонування електронної системи охорони } \\
\text { здоров'я. Пацієнт може самостійно або через }\end{array}$ \\
\hline
\end{tabular}


Закінчення табл. 3

\begin{tabular}{|c|c|c|}
\hline 1 & 2 & 3 \\
\hline & & $\begin{array}{l}\text { свого законного представника обмежити через } \\
\text { свій електронний кабінет доступ до інформації про } \\
\text { себе, що міститься в Реєстрі та зведеній медичній } \\
\text { інформації про пацієнта. Пацієнт також має інші } \\
\text { права щодо захисту своїх персональних даних } \\
\text { відповідно до законодавства про персональні дані } \\
\text { та електронну систему охорони здоров'я }\end{array}$ \\
\hline 2 & $\begin{array}{l}\text { Закон України } \\
\text { від } 19.10 .2017 \text { р. } \\
\text { № } 2168-V I I I \text { “Про } \\
\text { державні фінансові } \\
\text { гарантії медичного } \\
\text { обслуговування } \\
\text { населення” } \\
\\
\text { - Закон України “Про } \\
\text { захист інформації } \\
\text { у інформаційно- } \\
\text { телекомунікаційних } \\
\text { системах"; } \\
\text {-Закон України “Про } \\
\text { захист персональних } \\
\text { даних". }\end{array}$ & $\begin{array}{l}\text { Відповідно до ст. } 11 \text { Закону про фінансові гарантії } \\
\text { доступ до даних про пацієнта, що містяться в } \\
\text { електронній системі охорони здоров'я, можливий } \\
\text { лише у разі отримання згоди такого пацієнта (його } \\
\text { законного представника) у письмовій формі або у } \\
\text { формі, що дає змогу зробити висновок про надання } \\
\text { згоди [9]. } \\
\text { Без згоди доступ до інформації про пацієнта } \\
\text { можливий у випадках: } \\
\text { - наявності ознак прямої загрози життю пацієнта; } \\
\text { - за умови неможливості отримання згоди такого } \\
\text { пацієнта чи його законних представників (до часу, } \\
\text { коли отримання згоди стане можливим); } \\
\text { - за рішенням суду [9]. } \\
\text { Відповідно до ст. } 8 \text { Закону України “Про захист } \\
\text { інформації в інформаційно-телекомунікаційних } \\
\text { системах" інформація, яка є власністю держави, } \\
\text { або інформація з обмеженим доступом, вимога } \\
\text { щодо захисту якої встановлена законом, } \\
\text { повинна оброблятися в системі із застосуванням } \\
\text { комплексної системи захисту інформації з } \\
\text { підтвердженою відповідністю, що здійснюється за } \\
\text { результатами державної експертизи [14] }\end{array}$ \\
\hline 3 & $\begin{array}{l}\text { Постанова КМУ від } \\
25.04 .2018 \text { р. } \\
\text { № } 411 \text { “Деякі питання } \\
\text { електронної системи } \\
\text { охорони здоров'я” }\end{array}$ & $\begin{array}{l}\text { Регулюється порядок збору та обробки } \\
\text { персональних даних пацієнта у ЕСОЗ [11] }\end{array}$ \\
\hline 4 & $\begin{array}{l}\text { Правила забезпечення } \\
\text { захисту інформації } \\
\text { в інформаційних, } \\
\text { телекомунікаційних } \\
\text { та інформаційно- } \\
\text { телекомунікаційних } \\
\text { системах, затверджені } \\
\text { постановою Кабінету } \\
\text { Міністрів України від } \\
\text { 29.03.2006 р. № } 373\end{array}$ & $\begin{array}{l}\text { Пункт } 16 \text { Правил свідчить про те, що для } \\
\text { забезпечення захисту інформації в системі } \\
\text { створюється комплексна система захисту } \\
\text { інформації, яка призначається для захисту } \\
\text { інформації від: витоку технічними каналами, до } \\
\text { яких належать канали побічних електромагнітних } \\
\text { випромінювань і наведень, акустично-електричні } \\
\text { та інші канали, що утворюються під впливом } \\
\text { фізичних процесів під час фунцціонування засобів } \\
\text { обробки інформації, інших технічних засобів і } \\
\text { комунікацій; несанкіонованих дій з інформацією, у } \\
\text { тому числі, з використанням комп'ютерних вірусів; } \\
\text { спеціального впливу на засоби обробки інформації, } \\
\text { який здійснюється шляхом формування фізичних } \\
\text { полів і сигналів та може призвести до порушення її } \\
\text { цілісності та несанкціонованого блокування [15] }\end{array}$ \\
\hline
\end{tabular}


Закони України "Про державні фінансові гарантії медичного обслуговування населення", “Про захист інформації у інформаційно-телекомунікаційних системах", "Про захист персональних даних", Постанова КМУ “Деякі питання електронної системи охорони здоров'я” $€$ основними нормативно-правовими актами, які регламентують порядок збору та обробки персональних даних пацієнта у ЕСО3 [12; 9; 11].

Ведення медичної документації - одна з обов'язкових складових роботи лікаря. При цьому повнота отриманої інформації напряму залежить від того, наскільки коректно прописані усі суттєві дані.

31 березня 2019 р. в електронній системі охорони здоров'я України з'явилася можливість ведення електронних медичних записів. Електронний медичний запис - це елемент даних про пацієнта, що збирається в закладі охорони здоров'я та зазвичай зберігається в медичних інформаційних системах (МIC), якими користується цей заклад. Міністерством охорони здоров'я було запроваджено функціонування електронних медичних записів і рецептів в електронній системі охорони здоров'я.

Заклади охорони здоров'я, що збирають та зберігають електронні медичні записи, необхідні для надання медичних послуг, є володільцями таких даних з відповідними правами щодо обробки цих даних та відповідальністю щодо їх захисту та зберігання.

Уже з 1 квітня 2020 р. усі надавачі медичних послуг, які підписали договори з Національною службою здоров’я України на медичне обслу- говування за Програмою медичних гарантій, зобов'язані вести електронні медичні записи.

Порядок ведення Реєстру медичних записів, записів про направлення та рецептів в електронній системі охорони здоров'я був затверджений наказом Міністерства охорони здоров’я України від 28.02.2020 p. № 587.

Підписуючи декларацію про вибір лікаря, який надає первинну медичну допомогу, пацієнт (його законний представник) надає згоду на доступ до даних про нього, що містяться в електронній системі охорони здоров'я, такому лікарю, а також іншим лікарям за його направленням у межах, необхідних для надання медичних послуг такими лікарями.

Усі відомості або сукупність відомостей про пацієнта, є персональними даними пацієнта (ПІБ, дата народження, реєстраційний номер облікової картки платника податків, номер та серія паспорту або інших документів, що посвідчують особу, адреса проживання та інші дані, за якими можна ідентифікувати пацієнта). Згідно з формулюванням у Законі України "Про захист персональних даних", персональні дані відомості чи сукупність відомостей про фізичну особу, яка ідентифікована або може бути конкретно ідентифікована.

Метою впровадження комплексної системи захисту інформації в ЕСО3 є забезпечення конфіденційності, цілісності та доступності інформації.

Персональні дані пацієнтів у електронну систему охорони здоров'я можуть вводити визначені медич- 
ним закладом уповноважені особи. На них поширюється дія законодавства про лікарську таємницю і вони повинні забезпечувати захист таких персональних даних [12].

За розголошення медичних даних передбачена відповідальність (табл. 4).

Як видно з наведених даних, нормативно-правова база щодо предмета дослідження достатня, отже, зумовлені та узгоджені питання діяльності ЕСО3, поряд з тим, на нашу думку, видається необхідним глибше проаналізувати та покращити механізми моніторингу галузі охорони здоров'я з використанням електронних інструментів та можливостей електронної системи охорони здоров'я.
У сучасних умовах потрібно вчасно та якісно проводити моніторинг стану, змін та результатів діяльності охорони здоров'я, реформа галузі охорони здоров'я сприяє розвитку електронної системи охорони здоров’я (ЕСОЗ). Отримання достовірних даних, ефективна обробка, використання, оцінка медичних даних є базисом для формування висновків та прийняття управлінських рішень в галузі охорони здоров'я, які мають на меті покращення якості надання медичної допомоги населенню територіальної громади.

Висновки та перспективи подальших досліджень. Беручи до уваги дані огляду літератури та нормативно-правової бази щодо інформатизації галузі

\section{Нормативні документи, які передбачають відповідальність за порушення у сфері захисту інформації}

\begin{tabular}{|c|l|l|}
\hline $\begin{array}{c}\text { № } \\
\text { nор. }\end{array}$ & \multicolumn{1}{|c|}{$\begin{array}{c}\text { Назва нормативного } \\
\text { документа }\end{array}$} & \multicolumn{1}{c|}{ що регламентує } \\
\hline 1 & $\begin{array}{l}\text { Стаття 145 Кримінального } \\
\text { кодексу України }\end{array}$ & $\begin{array}{l}\text { Передбачена кримінальна відповідальність за } \\
\text { умисне розголошення лікарської таємниці особою, } \\
\text { якій вона стала відома у зв'язку з виконанням про- } \\
\text { фесійних чи службових обов'язків, якщо таке діяння } \\
\text { спричинило тяжкі наслідки [16] }\end{array}$ \\
\hline 2 & $\begin{array}{l}\text { Стаття } 182 \text { Кримінального } \\
\text { кодексу України }\end{array}$ & $\begin{array}{l}\text { Передбачена кримінальна відповідальність за пору- } \\
\text { шення недоторканності приватного життя (незакон- } \\
\text { не збирання, зберігання, використання, знищення, } \\
\text { поширення конфіденційної інформації про особу } \\
\text { або незаконна зміна такої інформації) [16] }\end{array}$ \\
\hline 3 & $\begin{array}{l}\text { Кодекс України про адмі- } \\
\text { ністративні } \\
\text { правопорушення }\end{array}$ & $\begin{array}{l}\text { За недодержання встановленого законодавством } \\
\text { порядку захисту персональних даних, що призве- } \\
\text { ло до незаконного доступу до них або порушення } \\
\text { прав пацієнта як суб'єкта персональних даних, } \\
\text { передбачена адміністративна відповідальність (ст. } \\
\text { 188-39 “Порушення законодавства у сфері захисту } \\
\text { персональних даних" та ст. 188-40 “Невиконання } \\
\text { законних вимог посадових осіб спеціально уповно- } \\
\text { важеного центрального органу виконавчої влади з } \\
\text { питань захисту персональних даних" [17] }\end{array}$ \\
\hline
\end{tabular}


охорони здоров’я ми свідомі перспектив раціонального впровадження та ефективної діяльності електронної системи охорони здоров'я на рівні об'єднаної територіальної громади.

Переконані, що в сучасних умовах інформатизацію галузі охорони здоров'я та діяльність електронної системи охорони здоров'я потрібно розглядати не лише як інструмент для автоматизації процесу внесення та обробки медичних даних, а й застосовувати та розвивати для ефективного управління галуззю охорони здоров'я на рівні об’єднаної територіальної громади.

Нормативно-правова база у вказаній сфері, як уже зазначалося, достатня. Поряд з тим, беручи до уваги вимогу інформатизації, потребу у якісних та достовірних статистичних даних та широке запровадження змін у сфері охорони здоров'я, вважаємо за доцільне провести оцінку та детальний аналіз існуючих вітчизняних і закордонних практик, інструментів та механізмів моніторингу сфери охорони здоров’я.

Крім того, на сьогодні існує потреба в детальному дослідженні результатів та вигод для управлінців, медичних працівників, пацієнтів, отриманих від інформатизації галузі охорони здоров'я. Необхідно також визначити корисні та проблемні сторони існуючих механізмів, модернізувати ефективні моделі, інструменти моніторингу, адміністрування i керування галуззю охорони здоров'я та пропозиції із впровадження оптимальних практик.

Також вважаємо за потрібне розширити застосування маркерів та стратегічних показників діяльності галузі охорони здоров'я на основі автоматизації обробки статистичних даних.

Інформатизація галузі охорони здоров'я проводиться як в Україні, так і за кордоном, вона пройшла шлях від реєстрів до єдиної електронної медичної картки. На сьогодні маємо фрагментарні дані щодо результатів впровадження механізмів моніторингу сфери охорони здоров'я як в Україні, так і за кордоном. Саме тому, вітчизняний та закордонний досвід у цій сфері стане об’єктом наших подальших досліджень.

\section{СПИСОК ВИКОРИСТАНИХ ДЖЕРЕЛ}

1. Рогова О. Г. Правові аспекти інформатизації охорони здоров'я України // Держ. буд-во. № 2/2017.

2. Степанов В. Ю. Інформаційний простір охорони здоров'я України // Теорія та практика публіч. упр. 2016. № 3 (54). C. 1-6. URL: http:// www.kbuapa.kharkov.ua/ebook/ tpdu/2016-3/doc/2/01.pdf (дата звернення: 14.06.2020). С. 4.

3. Ларіна Р. Р., Владзимирсъкий А. В., Балуєва О. В. Державний механізм забезпечення інформатизації системи охорони здоров'я: монографія / за заг. ред. проф. В. В. Дорофієнко. Донецьк: ТОВ “Цифровая типография”, 2008. 252 с.

4. Слабкий Г. О., Качур О. Ю., Кривенко $\epsilon . M$. Методологія вивчення рівня впровадження інформатизації в систему охорони здоров'я України: метод. рекомендації. Київ, 2014. 20 с.

5. Мінцер О. П. Інформатика та охорона здоров'я // Медична інформатика та інженерія. 2010. № 2. С. 8-22.

6. Конституція України, Закон України від 28.06.1996 № 254к/96-ВР. 
7. Національна стратегія реформування системи охорони здоров'я в Україні. URL: https://moz.gov.ua/ strategija

8. Про схвалення Концепції реформи фінансування системи охорони здоров’я. Розпорядження Кабінету Міністрів України; Концепція від 30.11.2016 № 1013-p. URL: https:// zakon.rada.gov.ua/laws/show/10132016-\%D1\%80\#Text (дата звернення: 20.12.2019).

9. Про державні фінансові гарантії медичного обслуговування населення. Закон України від 19.10.2017 № 2168-VIII. URL: https://zakon. rada.gov.ua/laws/show/2168 19\#Text

10. Основи законодавства України про охорону здоров'я. Закон України від 19.11.1992 № 2801-XII. URL: https://zakon.rada.gov.ua/laws / show/2801-12\#Text

11. Деякі питання електронної системи охорони здоров'я. Постанова Кабінету Міністрів України; Порядок від 25.04.2018 № 411. URL: https:// zakon.rada.gov.ua/laws/show/4112018-\%D0\%BF\#Text

12. Закони України "Про інформацію”, "Про захист персональних даних", "Про електронні документи та електронний документообіг”, “Про електронні довірчі послуги”, “Про Єдиний державний демографічний реєстр та документи, що підтверджують громадянство України, посвідчують особу чи їі спеціальний статус". URL: https://zakon.rada.gov. ua/laws/show

13. Деякі питання організації електронної взаємодії державних електронних інформаційних ресурсів. Постанова Кабінету Міністрів України; Порядок, Форма типового документа від 10.05.2018 № 357. URL: https://zakon.rada.gov.ua/laws / show/357-2018-\%D0\%BF\#Text
14. Закон України “Про захист інформації в інформаційно-телекомунікаційних системах" від 05.07.1994 № 80/94-BP. URL: https://zakon. rada.gov.ua/laws/show/80/94$\% \mathrm{D} 0 \% \mathrm{~B} 2 \% \mathrm{D} 1 \% 80$ \# Text

15. Правила забезпечення захисту інформації в інформаційних, телекомунікаційних та інформаційно-телекомунікаційних системах, затверджені постановою Кабінету Міністрів України від 29.03.2006 № 373. URL: https://zakon.rada. gov.ua/laws / show /373-2006$\%$ D0\%BF\#Text

16. Кримінальний кодекс України. Закон від 05.04.2001 № 2341-III. URL: https://zakon.rada.gov.ua/laws/ show/2341-14\#Text

17. Кодекс України про адміністративні правопорушення від 07.12.1984 № 8073-X. URL: https://zakon.rada. gov.ua/laws/show/80731-10\#Text

\section{REFERENCES}

1. Rohova, O. H. (2017). Pravovi aspekty informatyzatsii okhorony zdorovia Ukrainy [Legal aspects of informatization of health care in Ukraine]. Derzhavne budivnytstvo - State Formation, 2. Retrieved from http://www. kbuapa.kharkov.ua/e-book/db/20172/doc/5/02.pdf [in Ukrainian].

2. Stepanov, V. Yu. (2016). Informatsiinyi prostir okhorony zdorovia Ukrainy [Information space of health care of Ukraine]. Teoriia ta praktyka publichnoho upravlinnia - Theory and practice of public administration, 3(54), 1-6. Retrieved from http:// www.kbuapa.kharkov.ua/ebook/ tpdu/2016-3/doc/2/01.pdf [in Ukrainian].

3. Larina, R. R., Vladzymyrskyi, A. V., Baluieva, O. V. (2008). Derzhavnyi mekhanizm zabezpechennia informatyzatsii systemy okhorony zdorovia 
[State mechanism for informatization of health care]. V. V. Dorofiienko (Eds.). Donetsk: TOV “Tsyfrovaia typohrafyia" [in Ukrainian].

4. Slabkyi, H. O., Kachur, O. Yu., Kryvenko, Ye. M. (2014). Metodolohiia vyvchennia rivnia vprovadzhennia informatyzatsii v systemu okhorony zdorovia Ukrainy [Methodology of studying the level of implementation of informatization in the health care system of Ukraine]. Kyiv [in Ukrainian].

5. Mintser, O. P. (2010). Informatyka ta okhorona zdorovia [Informatics and health care]. Medychna informatyka ta inzheneriia - Medical informatics and engineering, 2, 8-22 [in Ukrainian].

6. Konstytutsiia Ukrainy : vid 28 chervnia 1996 roku [The Constitution of Ukraine]. (1996). Vidomosti Verkhovnoi Rady Ukrainy - Bulletin of Verkhovna Rada of Ukraine, 30. Art. 141 [in Ukrainian].

7. Natsionalna stratehiia reformuvannia systemy okhorony zdorovia v Ukraini na period 2015-2020 rokiv [National strategy for reforming the healthcare system in Ukraine for the period 2015-2020]. moz.gov.ua. Retrieved from https://moz.gov.ua/strategija [in Ukrainian].

8. Rozporiadzhennia Kabinetu Ministriv Ukrainy "Pro skhvalennia Kontseptsii reformy finansuvannia systemy okhorony zdorovia" : vid 30 lystopada 2016, 1013-r [Order of the cabinet of ministers of Ukraine "On approval of the Concept of health care financing reform" from November 30, 2016 № 1013-r]. zakon.rada. gov.ua. Retrieved from https://zakon. rada.gov.ua/laws/show/1013-2016$\%$ D1\%80\#Text [in Ukrainian].

9. Zakon Ukrainy "Pro derzhavni finansovi harantii medychnoho obsluhovuvannia naselennia” : vid
19.10.2017, № 2168-VIII [On state financial guarantees of medical care of the population Law of Ukraine of 19.10.2017, № 2168-VIII]. zakon. rada.gov.ua. Retrieved from https:// zakon.rada.gov.ua/laws/show/216819\#Text [in Ukrainian].

10. Zakon Ukrainy "Osnovy zakonodavstva Ukrainy pro okhoronu zdorovia” : vid 19.11.1992, № 2801-XII [Law of Ukraine "Fundamentals of Ukrainian legislation on health care" from 19.11.1992 № 2801-XII]. zakon. rada.gov.ua. Retrieved from https:// zakon.rada.gov.ua/laws/show/280112\#Text [in Ukrainian].

11. Postanova Kabinetu Ministriv Ukrainy "Deiaki pytannia elektronnoi systemy okhorony zdorovia" : vid 25.04.2018, № 411 [Resolution of the Cabinet of Ministers of Ukraine "Some issues of the electronic health care system” from 25.04.2018, № 411]. zakon.rada.gov.ua. Retrieved from https://zakon.rada.gov.ua/laws/ show/411-2018-\%D0\%BF\#Text [in Ukrainian].

12. Zakony Ukrainy "Pro informatsiiu", "Pro zakhyst personalnykh danykh", "Pro elektronni dokumenty ta elektronnyi dokumentoobih", "Pro elektronni dovirchi posluhy", "Pro Yedynyi derzhavnyi demohrafichnyi reiestr ta dokumenty, shcho pidtverdzhuiut hromadianstvo Ukrainy, posvidchuiut osobu chy yii spetsialnyi status". https://zakon.rada.gov.ua/laws/show [in Ukrainian].

13. Postanova Kabinetu Ministriv Ukrainy "Deiaki pytannia orhanizatsii elektronnoi vzaiemodii derzhavnykh elektronnykh informatsiinykh resursiv" : vid 10 travnia 2018, № 357 [Resolution of the Cabinet of Ministers of Ukraine "Some issues of organization of electronic interaction of state electronic information resources" from May 10 2018, № 357]. zakon.rada. 
gov.ua. Retrieved from https://zakon. rada.gov.ua/laws/show/357-2018$\% \mathrm{D} 0 \% \mathrm{BF} \#$ Text [in Ukrainian].

14. Zakon Ukrainy "Pro zakhyst informatsii $\mathrm{v}$ informatsiino-telekomunikatsiinykh systemakh" vid 05 lypnia 1994, № 80/94-VR [Law of Ukraine "On protection of information in information and telecommunication systems" from July 05 1994, № 80/94-VR]. zakon.rada. gov.ua. Retrieved from https://zakon.rada.gov.ua/laws/show/80/94\%D0\%B2\%D1\%80\#Text [in Ukrainian].

15. Postanova Kabinet Ministriv Ukrainy "Pro zatverdzhennia Pravyl zabezpechennia zakhystu informatsii $\mathrm{v}$ informatsiinykh, telekomunikatsiinykh ta informatsiino-telekomunikatsiinykh systemakh" : vid 29 bereznia 2006, № 373 [Resolution of the Cabinet of Ministers of Ukraine "On ap- proval of the Rules for ensuring the protection of information in information, telecommunication and information-telecommunication systems" from March 29 2006, № 373]. zakon. rada.gov.ua. Retrieved from https:// zakon.rada.gov.ua/laws/show/3732006-\%D0\%BF\#Text [in Ukrainian].

16. Kryminalnyi kodeks Ukrainy : vid 05 kvitnia 2001, № 2341-III [Criminal codex of Ukraine from April 05 2001, № 2341-III]. zakon.rada.gov.ua. Retrieved from https://zakon.rada. gov.ua/laws/show/2341-14\#Text [in Ukrainian].

17. Kodeks Ukrainy pro administratyvni pravoporushennia : vid 07 hrudnia 1984, № 8073-X [Code of Ukraine on Administrative Offenses from December 07 1984, № 8073-X]. zakon. rada.gov.ua. Retrieved from https:// zakon.rada.gov.ua/laws/show/8073110\#Text [in Ukrainian]. 